\title{
Sukoreno Site: Lost Classic Civilization
}

\author{
Ainur Rohimah ${ }^{1}$, Joni Wibowo ${ }^{2}$, Ricky Yulius Kristian ${ }^{3}$, Fitri Nura Murti ${ }^{4}$ \\ ${ }^{1}$ Indonesia Education Language and Arts Departments Faculty of Teacher Training and Education, University \\ of Jember, Indonesia \\ ${ }^{2}$ History Education Departments Faculty of Teacher Training and Education, University of Jember, Indonesia \\ ${ }^{3}$ Elementary Education Departments Faculty of Teacher Training and Education, University of Jember, \\ Indonesia \\ ${ }^{4}$ Indonesia Education Language and Arts Departments Faculty of Teacher Training and Education, University \\ of Jember, Indonesia \\ ${ }^{4}$ fitri.fkip@unej.ac.id
}

\begin{abstract}
The discovery of Statue and Red Bricks (Bata Abang) located in Sukoreno Village. The Red Brick in Sukoreno site has scattered in settlements and suspected that many Red Bricks has been crushed by residents. Being a cultural heritage of the past, this site needs deep attention and is very important to be studied as an Indonesian nation's self-image. The researcher used the folklore method to uncover the surrounding of the cultural and historical context. In addition, through physiological comparative studies, the shape and characteristics of decapitated statue and red bricks with Majapahit relics in Trowulan, it is found that decapitated statues (Sukoreno statues) have physiological characteristics (shapes and models) that are similar to the Nandiswara or Mahakala statues. The first identification lead the researcher how the connection of the Sukoreno Site with The East Majapahit Kingdom. This effort is expected to be able to support the development of the cultural tourism area in Jember Regency and contribute to the retention of assets of national culture, especially the culture of the people in Jember. This research concludes that The Sukoreno Site as an important area and assume The Sukoreno Site as a palace.
\end{abstract}

Keywords : Sukoreno Site; Folklor; East Majapahit Kingdom; Asoka Tree; Nandiswara Statue or Mahakala.

\section{Introduction}

Jember is an area in East Java that holds many historical stories that have not been resolved. "One of the mysteries of historical stories in Jember is the story of the Tigang Juru area, which is an anonymous area which refers to the eastern region of Lamajang (Jember, Bondowoso, Situbondo, and Banyuwangi)" (Jupriono et al. 2018: 138). The discovery of statues and Red Bricks (Bata Abang) in Sukoreno raised a big question about the traces of the Majapahit Kingdom scattered in the Jember region as alleged the relics of Rajasanegara's journey (Hayam Wuruk) to the eastern region, Brawijaya V escaped trail, or Sadeng's remnants of war. The initial identification of the findings led to the connection of the Sukoreno Site with the East Majapahit Kingdom.

(Jupriono et al. 2018: 169) Jember was also the area that had been passed by Rajasanegara on its short trip to the eastern region in September 1359. This was also evidenced by various sites found, especially in the southern Jember region, from the Kendeng Lembu Banyuwangi to Serampon, Puger Kucur to the west. The area was an area that had been passed by Hayam Wuruk, as written in Kakawin Dasawarnana where Hayam Wuruk traveled accompanied by Mpu Prapanca and the group had traveled hundreds of kilometers pulled by oxens to Lamajang and Tigang Juru (Jember, Bondowoso, and Situbondo) (Jupriono and friends, 2018: 181).

Findings of Bata Abang on the Sukoreno Site scattered in settlements and suspected to have been crushed by residents' houses. This was one of the factors that made it difficult for

\footnotetext{
${ }^{1}$ Lecturer of Indonesian Language and Literature Education, corresponding author.

${ }^{2}$ Student of Indonesian Language Education.

${ }^{3}$ Student of Historical Education.

${ }^{4}$ Student of Elementary School Teacher Education.
} 
researchers to be able to conduct in-depth searches on the Bata Abang site (artifacts) in Sukoreno. Until now, the identity of civilization in Sukoreno village couldn't be found. Only found some of Bata Abang stacked by residents in one location, namely the land of Reco.

Besides of it, a decapitated statue was also found which was considered by the people as an Arcaid of Shiva or Ganesha in the previous study referring to the statue of Dewi Yakshi because it was found near the Asoka Tree. Being a cultural heritage of the past, this site needs deep attention and is very important to be studied as an Indonesian nation's self-image.

To know the Sukoreno Site a lot of needs to be revealed. Not only on the form of the site, but also the myths that was exist in Sukoreno Village. This done because based on the state of the site, it was no longer possible to use the historical approach (artifact) In situ. Because the location of the artifact changed so that, the context was difficult to maintain. Therefore, researchers use folklore methods to uncover the surrounding context. Identification of Sukoreno sites in both forms and myths will help more in-depth and ongoing research into the Sukoreno Site.

\section{Research Methods}

This research is a qualitative research that aims to reveal the Sukoreno Site with a folklore approach. Qualitative research methods are designed in a manner that they help reveal the behavior and object perception with reference to a particular topic. There are different types of qualitative research methods like an in-depth interview, focus groups, ethnographic research, content analysis, case study research that are usually used

The first stage of this research is data collection related to the Sukoreno site through interviews, observation, and literature studies. Observations were carried out in Sukoreno Village, BPCB Jember, BPCB East Java (Trowulan), and Blambangan Museum (Banyuwangi). Interviews were conducted with informants namely customary stakeholders Mr. Widodo (45 years old) and Mr. Sucipto (47 years old), Mr. Sukidi/Kembut (witness / caretaker, 80 years), Mrs. Supini (wife of Mr. Sukidi, 67 years old), Mr Jari chief of RW (50 years old), Mr. Cipto (37 years old) and several residents of Sukoreno Village. Interviews were also conducted with an experts of history from Jember namely Mr. Zainulloh, S.Pd (45 years old), Mr. Didik, SS (Deputy Director of BPCB East Java Trowulan, 47 years old), Mr Hariri (Head of Service Unit of BPCB East Java, 39 years old), Riski (service clerk BPCB Jember, 28 years old, Bayu (service clerk Blambangan Museum, 32 years old).

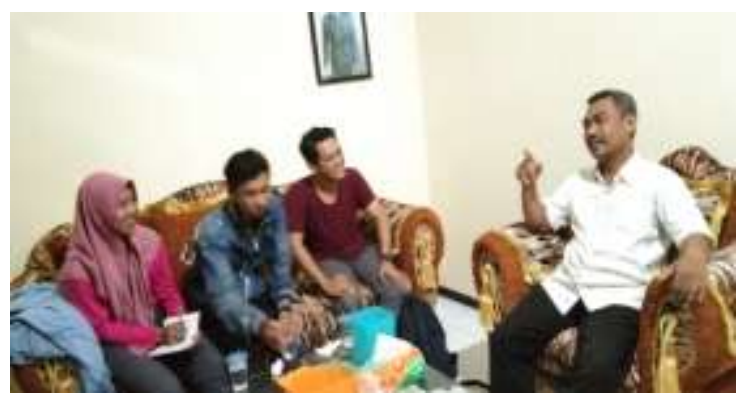

Figure 1. Interview with the people of Sukoreno 


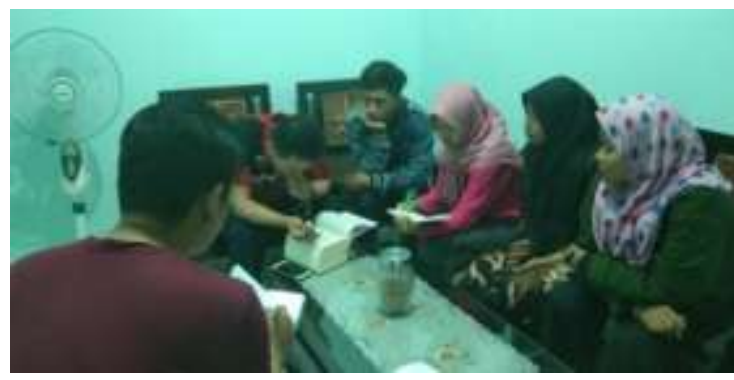

Figure 2. Interview with Mr. Zaenollah Ahmad

The researcher divided the data sources into two, primary sources and secondary sources. Primary data sources are stories, oral explanations of the citizens of Sukoreno and some historians, and the records of observations. Secondary data is supporting data sources from the literature.

The next stage is the classification and analysis of data. Data classification is done by making interviews, observation, literature studies, selecting and sorting data heuristically. Data analysis carried out by comparative studies and heuristic criticism regarding the shape and myths of Sukoreno Site artifacts. Data is processed by the source criticism method that is filtering out sources those are obtained critically so that produce sources of choice, both source material and source substance. Triangulation is done to find the validity of the data, both from the source (the right informant), the expert (folklore expert and historian), and the research method. In the data analysis phase, interpretation is done as part of analysis and synthesis. Data and facts that are separated from each other are coupled and incorporated into the whole context that surrounds it, resulting in a unified and intact unity. Drawing conclusions is done deductively. Collection and presentation of data from general to specific conclusions.

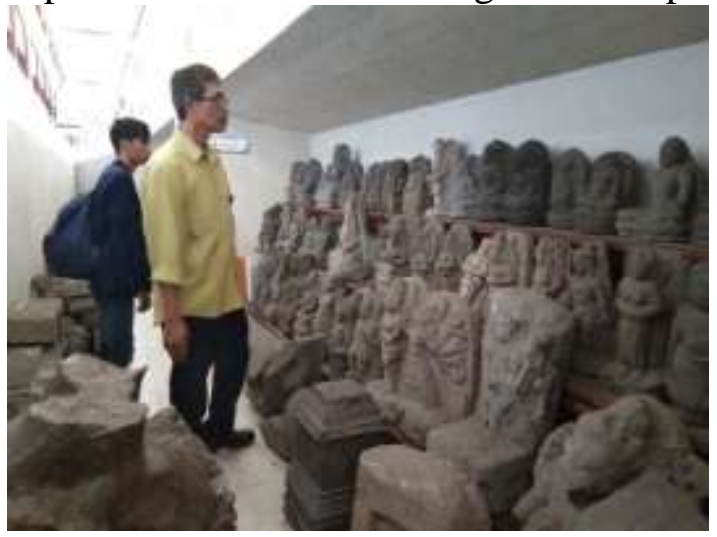

Figure 3. Discussion with The Trowulan Museum

The final stage of this research is research or historiography. Historiography is also manifested as a Supporting Script for Cultural Asset Inventory (academic) submitted to BPCB Jember as a description of the Sukoreno Statue which is now stored in BPCB Jember. This effort is expected to be able to support the development of the cultural tourism area of Jember Regency and contribute to the retention of assets of national culture, especially the culture of the people of Jember. 


\section{Sukoreno Site in Folklor Glasses}

Folklore is a part of the culture of a collective that is spread and passed down from generation to generation. (Danandjaya 1984: 2) "Folklore is part of a culture of a collective that is spread and inherited from generation to generation traditionally in oral form and accompanied by other reminders". One form of fochlor is a myth. Myths are symbolic and sacred stories about ancient stories containing interpretations of the origins of the universe, humans, and certain societies. (Sukatman 2011: 10) "The myths in Indonesia are disseminated and transmitted in the form of hybrids (chime) with other forms of tradition that are very diverse and not in the form of myths".

Folklor is often wrapped up in myths. according to (Sartono Kartodirdjo 1992) "The Myth is a prototype of history, namely the transition from a non-historical nature to a historical realm. In ancient times myths were used to make the past meaningful". The story of the story based on the chronicle is packed with elements of myth but is based on historical facts.

Likewise the context of the Sukoreno Site. The Sukoreno site is surrounded by mystical experience and beliefs. The community has certain beliefs regarding the site. First, it is forbidden to move the Bata Abang. If you move it, the person who removes it will get sick and can be cured if the brick is returned to its original place. Secondly, it is forbidden to pick leaves or flowers from the Three Asoka Trees those are on the ground founded statues (reco land), Third, the only person who can carry Arca Sukoreno (decapitated statues) is Mr. Sukidi / Kembut (Site Key Interpreter). Fourth, if the community has a ceremonial (eg marriage) should offer offerings on reco land.

\section{Traces of Classical Civilization in Jember}

(Jupriono et al. 2018) explained that classical history (Hindu-Buddha) in Jember has lasted more than 1000 years. which marked the diversity of archaeological heritage in Jember in the classical period. The researcher suspects that there is a link between the Sukoreno Site and several kingdoms that once existed in Jember. As a site, still minimum information from Sukoreno Site. Some assumptions point to the Majapahit Kingdom, although there is never a logical explanation for this assumption. However, this assumption developed among the community. The discovery of a statue with a severed head, Bata Abang (already not in situ) and Asoka Tree which has historical value for Sukoreno Village is considered to be related to the East Majapahit Kingdom.

Another possible presumption is that the Sukoreno Site is closely related to the history of ancient cities in Jember. Based on the location of the site, geographically it can be seen very close to the sites of ancient cities in Jember. There is a site with the names of Kutho blater, Kutho Boro, Kutho Kedawung, Poeger Wetan in common. These ancient cities site are very close to the Sukoreno Site.

In the Book of Nagarakertagama, ancient bricks in the classical era were known as "Bata Abang". The Sukoreno site has a legacy in the form of a Bata Abang which is believed to still be buried under the people's settlements, that make the Sukoreno Site difficult to study. Some residents who are aware of Bata Abang collected ancient brick findings on the land of Reco. This Bata Abang collection makes the artifacts no longer in situ. It is necessary to have in-depth research to find out the civilization that once existed in Sukoreno Village. Revealing the history of the Site Sukoreno which has limited and no in situ archaeological information and evidence is very difficult if done using historical methods only, so folklore is needed to find the context surrounding the Sukoreno Site. 


\section{Sukoreno Site and East Majapahit Kingdom}

There is information that the Sukoreno Site is a legacy of the Majapahit Kingdom in Jember, but there is no in-depth study on this matter. In fact, none of the literature in the history of Jember searches mention the Sukoreno Site. However, there is an interesting thing in the journey of the Worship of Hayam Wuruk (Rajasanegara) to Jember written in the book Desawarnana, interpreted as "Description of the Villages". This book is not just a literary work, but is one of the important documents for National History. Dasawarnana describes various events and places that the king and his entourage passed. As mentioned by historians (W. Fruin 1919; Jupriono et al. 2018: 169) in the short route Hayam Wuruk's trip to the east departs from the Trowulan (Majapahit) through Mojosari highway (now) and arrives at Kapulungan (Gempol-Pasuruan), the next route is through Bangil (Pasuruan) and Lake Grati to Baremi village (including Probolinggo) then turn south through Klakah lake and enter Lumajang city before arriving at (beach) Kamirahan on the southern seafront of Lumajang. Next, comb the coastline to Sadeng (enter in the Jember area).

The journey into the Jember area passes through the southern route, but also through Kasogatan Brajaka in previous, then towards Rabut lawing then enter Blater (Head of Blater Village). In this case, Hadi Sidomulyo said that the Blater Urban Village was in the southern region of Gumukmas assuming the topography in the form of a village (swamp) which is now very compatible with the Topography of Mayang Gumukmas Village (Jupriono et al. 2018: 169). If the Sukoreno Site has a relationship with the Majapahit Kingdom, then it is certain that the king's crossing path will pass through this area as a sign of the king's territory, accessible from the travel story. Hayam Wuruk after passing Lumajang. On the lake which is located at the foot of the Lamongan Raja mountain, stays a day. Then, the train ridden by King Hayam Wuruk passed Arenon (Kutorenon), Panggulan, Panyaman, Tepasana, Khutorembang, and then drove to the south before finally the group arrived at Kamirahan (now Bambang Beach) in the southern sea.

Next, pass Patunjungan, Danau, Whedi and Guntur. The next journey of King Hayam Wuruk and his group arrived at Kasogatan Brajaka, which is now estimated to be the village of Cakru, Kencong sub-district. There according to (Zainulloh 2010: 131) quotes that Mpu Prapanca was recorded which was pronounced at Patunjungan, considered to require traces or even warfare. The expected war could be Sadeng War in 1331 (28 years after King Majapahit's visit).

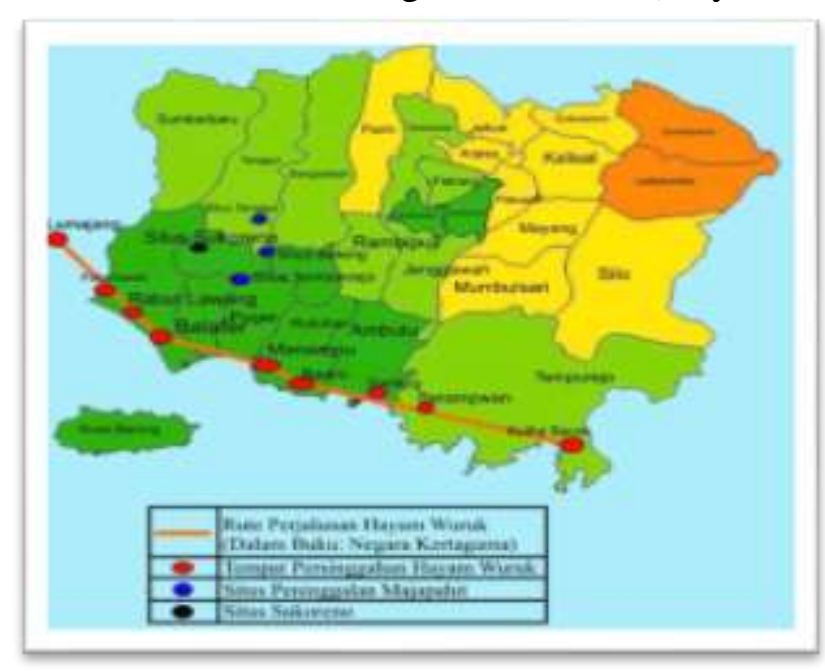

Figure 4 Map of Majapahit History 
One thing that can strengthen the linkage of the Sukoreno Site as part of Majapahit is the journey of Rajasanegara which runs through the area of South Jember. However, this thesis cannot be final because the archaeological evidence found is very lacking and the interpretation of Rajasanegara's journey in Jember is not detailed and complete. However, the large number of Majapahit heritage buildings surrounding the site indicates that the sites in Sukoreno could be related because if viewed on the map these sites are now close together.

\section{Asoka Tree in the Majapahit Kingdom}

(Regina 2010: 185) from the results of her research explained "The Asoka Tree is described as being close to the palace nobles and depicting the palace atmosphere". Asoka plants as written in the Desawarnana manuscript: Nagarakertagama translation of Robson mentioned that the vast royal courtyard was planted with large trees so that guard soldiers took refuge under the tree. The royal yard was also used as a meeting place between honorable people and the king. They met each other under the Asoka tree which was located adjacent to the main palace (Satari 2008: 129). In the Nagarakertagamapupuh text 10.3, it is stated that the Asoka tree is located adjacent to the meeting place of the Kshatriyas (nobles), Bhujanggas, rsi (monks), Wipra (Brahmin), and this location is part of the palace (Pigeud III 1960: 13). It is strongly suspected that the Sukoreno Site was a part of a palace. It is not certain at when the King ruled at that time.

The Asoka plant is considered a sacred plant by Hindus-Buddhists. The Asoka Tree on the Sukoreno Site now has three trees left. Mr.Sukidi, 80 years old (interview, 13/4/2019) said that before being cleared, Asoka trees were widely scattered around the discovery of statues. The discovery of the scattered Asoka Tree was thought to have been a meeting place between honorable people and the king. According to an interview with the customary head of Sucipto (12/30/2018), residents of Sukoreno Village tried to reforest Asoka's trees so it would not become extinct. However, many Asoka Trees did not succeed in living. Sucipto (47 years old) believes that this is a mystical event. The Asoka tree in Sukoreno Village is a legacy of the Majapahit Kingdom and is difficult to grow today.

On the official website of PEMKAB Jember (http://www.jemberkab.go.id/situsbeteng-semboro/) which reviews the Semboro Beteng Site describing that the Beteng Site was built by Raja Kertabumi or Brawijaya V. It is said that Majapahit was attacked by the kingdom of Demak by Raden Patah who is also a child from Brawijaya V. After Majapahit was defeated, Brawijaya V and all of his troops fled to Tengger. Raden Patah pursued Raja Brawijaya V to Tengger until finally Brawijaya $\mathrm{V}$ ran to Jember and built a fort. Because the distance of the Beteng site in Semboro is $11 \mathrm{KM}$ away with Sukoreno Site, it can be expected that the site has a connection with the Beteng Site which is a legacy of the Majapahit civilization.

\section{Decapitated Head Statue: Nandiswara or Mahakala}

In the initial study researchers suspected that Sukoreno Decapitated Head Sculpture was the Statue of Dewi Yakshi. The assumption is based on the location of the statued near the Asoka Tree. Goddess Yakshi is a partner of the God of Yaksha who is a god of well-being and she is a treasure guard. (I Wayan 2016: 3) "The statue of the Goddess Yakshi is depicted by the foot stepping on the base of the stem and the hand holding the branch of the Asoka Tree and appearing with jewelry and gems that usually embrace plants". However, the assumption pulled by the researcher (revised) because the characteristics of the Sukoreno's Statue also do 
not find the same characteristics with the Statue of Dewi Yakshi. The existence of the Asoka Tree is not strong enough to ensure that the Sukoreno Statue is a statue of Dewi Yakshi.
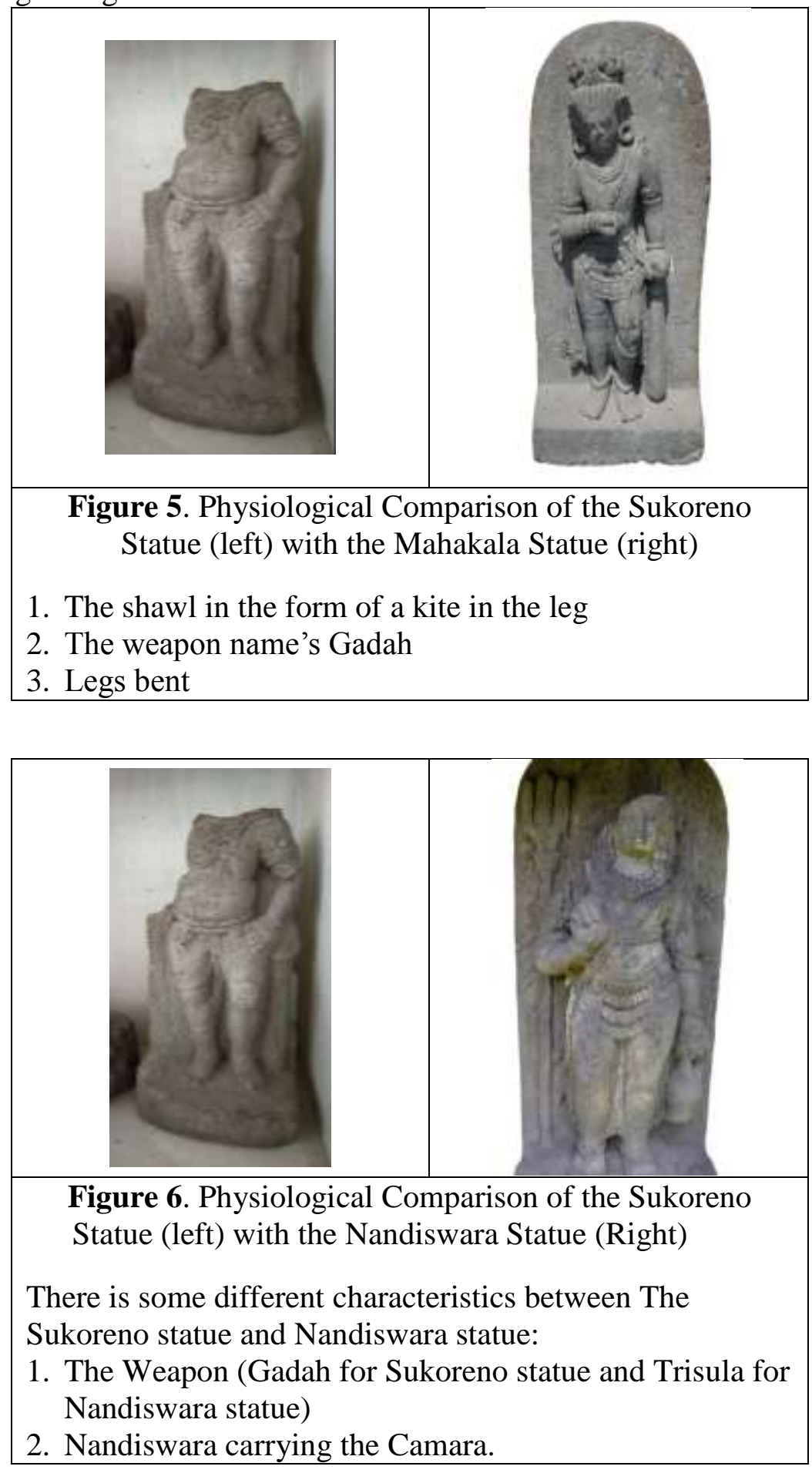

Through physiological comparative studies, the shape and characteristics of statues of heads are decapitated with Majapahit heritage statues at Trowulan, it is found that decapitated statues (Sukoreno statues) have physiological features (shapes and models) similar to the 
Nandiswara or Mahakala statues. The similarity of these characteristics is that the legs always bend, the right or left hand holds the mace, and the scarves on the left or right hand. According to Mr.Didik Purbandiyo (interview, 05/24/2019) "Nandiswara statues and Mahakala statues are part of the god Shiva (place of worship) which is in charge of guarding the holy place. Sukoreno Village was found by the Asoka Tree which is considered sacred by Hinduism, which means the place is a sacred area ".

Mahakala in Hindu methodology as the Shiva ruler of time, be on duty to guarding the entrance of the temple to the left. Mahakala stood with his left foot straight and his right leg bent forward slightly, face worn. Mahakala uses kundala, short necklaces, wristbands and anklets, standing position. Two-handed and the right hand carries a heirloom that leads to the back and wears cloth over the ankles. The next statue is Nandiswara, an aspect of Nandi in the form of Antropormorfik (human form) be on duty to guarding the entrance of the temple on the right. (Hartono 2014: 72) "Arca in a standing position with the right foot slightly bent and left foot straight, behind there is Sirascakra. Armed two, right hand bent up front carrying camara, left hand hanging down, next to waist carrying a jug and on the right side there is a trident.

The similarity of the characteristics of the Sukoreno statue with the statue of Nandiswara or Mahakala is still weak and references that can be strengthened is needed. This finding cannot be agreed upon or absolutely recognized and needs to be identified again.

\section{Conservation of Sukoreno Site}

Sukoreno site needs to conservation as a material and science. Law of the Republic of Indonesia Number 11 of 2010 concerning Cultural Heritage, Chapter I article 1 explains that "Cultural heritage is material cultural heritage in the form of cultural heritage objects, cultural heritage buildings, cultural heritage structures, cultural heritage sites, and cultural heritage areas on land and/or in the water that needs to be defined because it has important values for history, science, education, religion and/or culture through a fixing process". This site needs helped because Red Bricks scattered in settlements and suspected to have been crushed by residents' houses.

As a cultural sience that was very important because this site have located of three sites in the form of fortrees wall are like circling / protecting the Umbulsari area specifically including the Sukoreno Site, this site need to be investigate to explore Classical History in Jember. As a cultural heritage the founding of sukoreno site needs to be attended by government. Reefering to the Cultural Heritage Law Chapter 2 article 5 "Objects, buildings, or structures can be proposed as objects of cultural heritage, cultural heritage buildings, or cultural structures if they meet the criteria: a. 50 (fifty) years or more; b. representing the shortest style period of 50 (fifty) years; c. has special meaning for history, science, education, religion, and / or culture; and d. has cultural values for strengthening the nation's personality. From this research Sukoreno site have to conservation because this site have special meaning for history, science, education, religion, and culture.

Based on the law, the author seeks the Sukoreno Site can be conserved as part of the cultural heritage and state assets that need to be preserved. This research can help the BPCB as the organization government to get the data to conservate. The author make the handbook to inform the public about this site. it's a part of our contribution to educate public. 


\section{Conclusion}

Arca, Bata Abang, and Asoka Tree are historical artifacts that can be used to reveal the existence of the East Majapahit Kingdom in Jember region. Through this research the public assumption that the Sukoreno Statue is a statue of Ganesha or Shiva is broken by a test of physiological comparison of statues. The Sukorena statue is more like the Arca Nandiswara or Mahakala because it carries a mace weapon with the legs bent. Although this thesis is still not bright because the determination of Nandiswara or Mahakala lies in the missing head. Nandiswara has a human head, while Mahakala has Kala or Buta (giant) head.

The discovery of the Ashoka Tree in a kingdom is very close to the palace garden. This finding shows that the Sukoreno Site can be assumed to be the meeting place of the Kshatriya (nobility), Bhuhanggas, rsi (monks), wipra (Brahmin), and this location is part of the palace.

The Sukoreno site if examined from its geographical location with adjacent sites such as the Semboro Beteng Site, the Pengungan Tanggul, and the Tembokrejo Gumukmas have inheritance forms such as the bull wall. The locations of these three sites are like circling / protecting the Umbulsari area specifically including the Sukoreno Site. Sukoreno site is an important site that needs to be studied and protected.

\section{Acknowledgements}

All thanks, the author prays to God Almighty for the gifts that have been given so that the author can complete this pocket book. With humility the author presents this small work as a greeting of thanks, devotion and love of the author at:

- Beloved parents. Thank you for being an extraordinary parent for the writer in the form of love, support, warm hugs so that the writer can be a person who is able to benefit others. Thank you for your prayers and love.

- Miss Fitri Nura Murti S.Pd., M.Pd. as a lecturer that I am proud of. He as the supervisor of the Student Creativity Program who has guided the author with a warm hug. The sweet and bitter that we feel has shaped the writer to be a strong and strong person so that all the obstacles can be conquered.

- Jember Cultural Conservation Center (BPCB). We dedicate this book to BPCB Jember in order to provide public information about the Sukoreno Jember Site.

- Sukoreno village. This book is the author's dedication to Sukoreno Village as a reference for the village so that they can introduce Sukoreno Village Site to the public.

- University of Jember which has been fostering. Thank you to the entire bureaucracy of the University of Jember especially the leaders of the rector who have become organs that have supported the author in the aspects of fostering and supporting both moral, support and financial.

- Thank you to the Ministry of Research, Technology and Higher Education which has held a Student Creativity Program and supports the author's research. Trima kasi has created a forum for writers as a learning process and expresses their ideas and concerns. 


\section{References}

Danandjaja, James. 1984. Folklore Indonesia. Jakarta: PT. Grafiti.

Hageman, J.J.Cz. 1852. Handleiding tot de Kennis der Heschiedenis, Aardrijikunde. Fabelleer en Tijd rekenkunde van Java I. Batavia.

Hartono, Tri, dkk. 2014. Katalog dan Kolegsi Arca Batu. Yogyakarta: Balai Pelestarian Cagar Budaya.

Jupriono; Zaenollah Ahmad; Didik Purbandiyo. 2018. Jember Dari Waktu Kewaktu: Sekilas Wakil Rakyat dan Perkembangan Kabupaten Jember (Prasejarah s.d 1970an). Jember: Sekretariat DPRD Kabupaten Jember.

Kroom, N.J. Inleeading tot de Hindoe-Javaansche Kunst, II. 's-Gravenhage.

Mees, W. Fruin. 1919 Geschiedenis van Java deel I het Hindoetijdperk, Weltevreden: Commissie voor de Volkslectuur.

Pigeaud, H.G.T. 1960-1963. Java in the 14 ${ }^{\text {th }}$ Centur: A Study in Cultural History: The Nagarakertagama by Rakawi Prapanca of Majapahit. 1356 Ad. 5 vols. The Hague. Martinus Nijhoff (KITLV Translation Series 4).

Regina, Y. 2010. Beragaman Tanaman Pada Relief Candi Di Jawa Timur Abad 14 Masehi (Kajian Bentuk dan Pemanfaatan). Bekasi: Universitas Indonesia.

Sukatman. 2011. Mitos Dalam Tradisi Lisan Indonesia. Jember: Center for Society Studies Jember.

Satari, Sri Sojatmi. 2008. "Ancient Gardens and Hindu-Buddhist Architektur Java” dalam buku Interpreting Southeast Asia's Past: Monument, Image, and Text. Bab 9 halaman 122. Singapore: Nus Press.

Undang-Undang Republik Indonesia Nomor 11 Tahun 2010. Cagar Budaya. 24 November 2010. Lembaran Negara Republik Indonesia Tahun 2010 Nomor 130. Jakarta. 